\title{
National Security Redesign after the COVID -19: Nepali Army's Security Priority in Response to the Global Pandemics
}

\section{Padam Kumar Angbo}

\begin{abstract}
Pandemic disease always poses one of the greatest security threats to national security. It is widely discussed as a non-traditional threat candidate to national security (NDU, CACI, The Asymmetric Threat Symposium, 2008,
\end{abstract} p. 31). Indeed, the COVID- 19 has not only unleashed havoc on developing nation but also provided a vital national security lesson exposing weaknesses in their capabilities to protect citizens. For example, Nepal has lost more than 2000 lives of its people and about 271,000 have severely suffered this viral infection, and the deaths with this pandemic in the US and UK are even higher. And the trend of causalities has increasingly been continuing along with an alarming rate of infection. Meanwhile, a new deadly variant of corona virus is swiftly spreading across the globe including Nepal. This study employs the qualitative research framework and data have been employed from secondary sources. The research philosophy adopted is interpretivism where the researcher has included his viewpoints to available data in presenting ideas. The article explores causes and multi-dimensional effects, critical nexus between COVID- 19 and National Security in support to the argument that the nature, scope, novelty and complexity of COVID- 19 pandemic demands an Integrated National Security Strategy for an effective application of all the instruments of national power, including Nepali Army, public and private sector to respond successfully. This paper also spotlights the crucial role of Nepali Army in containing pandemics that proffers to reappraisal of such a vital security body's strategies and doctrines, taking the current corona virus in serious consideration.

Keywords: COVID-19, pandemic, pontraditional asymmetric threat, national security, integrated security strategy

\section{Introduction}

Pandemic disease always poses one of the greatest security threats to national security. It is widely discussed as a non-traditional symmetric threat candidate to national security (NDU, CACI, the Asymmetric threat Symposium, 2008, p. 31). Indeed, the ongoing COVID -19 pandemic has not only unleashed havoc on developing nation but also provided a vital national security lesson, exposing weaknesses in their capabilities to protect their citizens. For example, as of 5 February 2021, Nepal has lost more than 2000 lives of its people and about 271, 000 have severely suffered this viral infection, and the deaths with this pandemic in the US and the UK are even higher. And, the trend of casualty has increasingly been continuing along with an alarming rate of infection. Meanwhile, a new deadly COVID-19 variant is fast spreading across the globe including Nepal. An explosive outbreak can take place at any time in Nepal too. It poses a great potential threat to the prevention and control of COVID-19. Foregoing in view, this paper 
explores causes and multi-dimensional effects, critical nexus between COVID -19 and national security in support to the argument that the nature, scope, novelty and complexity of COVID- 19 pandemic demands an Integrated National Security Strategy for an effective application of all the instruments of national power, including Nepali Army. This article also spotlights the crucial role of Nepali Army in containing pandemics that offers to reappraisal of such a vital security body's strategies and doctrines, taking the current corona virus in serious consideration.

This paper aims at exposing how pandemic diseases like COVID-19 threatens national security and proffer some strategic options that will enable our policymakers to prevent and respond to such threats in Nepal. Moreover, the current paper, which is organized into five parts, including Notion of national security, the linkage between COVID- 19 and national security, Nepali Army in the war on Corona virus, analysis of causes and impact and ways forward.

\section{Methodology}

This study follows the qualitative research framework and data have been employed from secondary sources. The researcher mainly used journal articles and relevant websites to acquire data for the study. Since the COVID-19 is an ongoing pandemic crisis across the globe including Nepal, the study focused on information till 05 February 2021. The research philosophy adopted is interpretivism where the researcher has included his viewpoints to available data in presenting ideas.

\section{Literature Review}

The research reviewed books, research papers and grey literature (newspaper articles and blogs) to understand the consequences of COVID-19. Available literatures mostly focus on assessing macro impacts. Despite utmost importance to assess the impact on national security, the literature is still limited. The most of literature regarding COVID-19, for instance, Asymmetric Threat Symposium( NDU, CACI, 2008), Tribhuvan University Journal, COVID-19 Special issue ( 2020), Nepal's National Security Policy 2016, Pandemics and National Security (Evans, 2020), are important for this article. Significant number of domestic literature argues that the pandemic response strategies adopted by nations including Nepal were inadequate and incoherent exposing weakness to protect people from mass killer virus. NDU, CACI, the Asymmetric threat Symposium (2008) logically concedes that among others, pandemic is an asymmetric threat candidate to national security and demands an appropriate response strategy. Adhikari (2020, p. 15) makes a perspective of the realism theory of International Relations to make the relationship between microorganisms and state affairs and confirmed that security is a link between microorganisms and realism. While delving on the socio economic impact of COVID-19, the article of Chaudhary (2020, p. 69) suggests OLS model for forecasting the loss of economic growth rate through the chain process of remittance and growth of domestic product in the country. Besides, Bhattrai \& Baniya (2020, p. 129) explore situations of Nepali migrant workers in major destinations and discusses the factors that shape a sense of insecurity / security during pandemic era. Further, UK's National Security Strategy has classed pandemic as tier 1 risk to national security. The US National Strategy for Pandemic Influenza 2005 presents US approach to address the threat of Pandemic 
Influenza. Likewise, in the US, the NSC's Directorate for Global Health Security and Biodefense was established in 2015 by the Obama administration. But the Trump administration disbanded it in May 2018. Similarly, National Security Policy of Nepal 2016 had the briefest mention of epidemics and other infectious diseases as threat to national security. The importance of health to the security of the Nepal, to its economy, and to the well-being of its people is a key finding from the mentioned literature survey.

\section{Historical Background of COVID-19}

The first case of acute respiratory syndrome coronavirus 2 (SARS-CoV-2)/ COVID-19 was reported from Wuhan City in Hubei province, China on 31 December, 2019. The World Health Organization (WHO) declared COVID-19 a public health emergency of international concern on 30 January 2020 and, because of the worldwide spread, a pandemic on 11 March 2020 (WHO, 2020). In February 2020, with the first corona related death in France and a sharp increase of COVID-19 positive cases in Italy, the corona virus became a matter of significant concern in Europe. The first case of covid-19 was officially announced in Nepal on 24 Jan 2020.Currently, COVID-19 continues to swiftly spreading across the globe including Nepal. Globally, as of 05 February 2021, there have been 104,790,123confirmed cases of COVID-19, including 2,285,048 deaths, reported to WHO. The above scenarios depict that the potential impact is terrific in terms of national interest.

\section{Notion of National Security}

In the past, the state was the traditional focus of security policies of countries including that of Nepal. Of late, experts view on national security has broadened to include threats to individual citizens. Subsequently, Infectious diseases (IDs) like COVID- 19 are considered threats to nation's security in the strategy documents. For example, the European Union's Global Strategy of 2016 highlighted the detection, prevention and response to global pandemics as a priority. UK assess that the emergence and spread of microbes with potential to cause pandemic as a significant concern (UK's NSS \& SDR, 2015, p. 18). Likewise, Nepal's National Security Policy, 2016 mentions epidemics and other infectious diseases as threats and challenges to national security (MOD, 2016,p. 13 ). So we should have seen it coming. Despite all of these efforts, COVID-19 has surprised Nepal in an unprecedented manner, severely impacting vital national interests, failed to protect citizens. The corona related death toll has surpassed 2000 lives and infected more than 271,000 people (MOH, 2021). Against this backdrop, it is imperative to discuss the nexus between pandemic like COVID- 19 and National Security.

\section{Linkage Between COVID 19 and National Security}

Corona virus is a microorganism and ubiquitous in nature and is dangerous to human beings causing infectious disease. Throughout history, nothing has killed more human beings than infectious disease. For example, influenza pandemic of 1918-19 is estimated to have killed more than 50 million worldwide, which is more than what World War I killed in action i.e. about 20 million. When the virus affects a few people within a specific area, its control falls within the domain of health sector. On the other hand, when these viruses spread on a big scale without respecting the boundaries, it could become a concern for the all elements of 
national power. The result could be severe disruption of normal life. People feel unsafe even when they are at home. Thus the spread of pandemic disease like COVID-19 in a large populace becomes a security concern.

Apparently, the rapid spread of COVID-19 threatens the national interests of Nepal. It is poised to reduce the capacity of a state to govern efficiently because it can accelerate poverty, intra-state violence, economic instability, and political instability ultimately undermining national security with a further erosion of trust in public institutions. Precisely, COVID- 19 can threaten the national security of Nepal in multiple ways. First, it can cause increase in illness putting huge stress on peoples' health and the nation's labor force leading to economic recession and political instability. Secondly, the devastating effect of swiftly spreading disease COVID- 19 is somewhat similar to deliberate biological weapons attack which represents the most direct threat to national security. Therefore, the preparation for the widespread disease COVID-19 should be at the center stage of national security. Thirdly, the pandemic poses indirect threats to national security which include the health of Nepali Army- the national defense forces. Finally, weakening of the state capacity will have negative impact on security and violence during and post pandemic era. Increasing unemployment, poverty, and a growing sense that the state cannot fully address these problems may contribute to political turmoil. For instance, Nepali youth shouted slogans as they gathered for a protest near prime minister's residence demanding better handling of the COVID-19 pandemic (The Diplomat, 29June 2020). The current volatile situation in Nepal is in some ways indirectly connected with the poor handling of pandemic by the state. Indeed, Infectious diseases threaten national security, both internally and externally (Evans, 2010, p. 108). The government's apt decision to mobilize Nepali Army- a vital instrument of national security to protect people from virus also shows not only the gravity but also the inherent linkage between the pandemic and security.

\section{Nepali Army (NA) in the War Against COVID 19}

Thus, like in any disastrous situation, Nepali Army as a vital instrument of national security has been called out to fight against a new kind of war since the early days of COVID-19 crisis in Nepal. Going beyond the call of duty, Nepali Army focused its efforts to combat global pandemic COVID-19 for a noble cause-protection of people from killer virus. As the crisis situation unfolded, it shouldered unprecedented numerous multifarious tasks inter alias, some of the key tasks include firstly, it spontaneously agreed to take responsibility to import necessary medical equipment for COVID- 19 amid corruption allegations to OMNI group. Nepali Army was pointlessly blamed, when the government entrusted such critical role. For example, the Record (2020) cautioned, at this point, Nepal's national army seems poised to utilize the crisis as yet another opportunity to bolster its influence. Similarly, Giri \& Ghimire (2020) contend that government's decision to rope in the Nepal Army to procure medical equipment necessary to combat the Covid-19 pandemic has drawn criticism from across the political spectrum that the national defense force is getting increasingly politicized and is losing its identity as a neutral national institution.

Secondly, it assisted civil authorities in imposing lockdown measures in different 
parts of the country. Thirdly, Nepali Army provided medical expertise to handle COVID-19 cases which included evacuation of 175 Nepali citizens from Wuhan, China. It was one of the biggest corona related evacuation operations in the history of Nepal (Sipahi, 2020, p. 1). Fourthly, it helped set up significant number of Quarantine centers and its security management across the country. Fifthly, Nepali Army is responsible for corona related dead body management- a novel call of the duty; so far it has disposed of bodies of about 1000 corona related deceased as per Ministry of Health and Population guide line on "Dead Body Management of COVID 19 Cases". Regarding the procedure, hospitals first inform the Covid-19 Crisis Management Centre, which then informs the respective Division Headquarters. It sends teams prepared for cremation of bodies of corona virus victims. Sixthly, the NA assisted in managing of return of immigrant workers across Indo- Nepal border. As India imposed nationwide lock down since 24 March 2020, many Nepali migrant workers returned to the country only to be denied access to Nepal due to lock down situation in Nepal too. Consequently, thousands of Nepali migrant workers stranded at different locations along the border. Seventh, the NA has been providing holding area security and running many health desks. Eighth, the NA developed COVID-19 App to help facilitate contact tracing. Ninth, the NA ran sensitization programs about COVID-19 for people. Currently, Nepali Army has deployed more than 21000 personnel in support to authorities to curbing the spread of COVID-19 in different parts of the country. While discharging COVID 19 related duties, more than 3000 Nepali Army personnel including soldiers and senior officers had been infected from corona virus. Two of those infected Army soldiers lost their lives.

With the unfolding of vicious spread of invisible enemy, the NA exposed to unprecedented hardships and challenges. Some challenges facing the NA in its campaign against COVID-19 primarily include managing its human resources, limited equipments, coordination with other sectors and lack of emergency guide lines during crisis period. While it is indisputable that responding the pandemic has been the security priority of the NA and it has left no stone unturned to accomplish the mandated mission, many invaluable lessons on pandemic response are learnt from experience. Indeed, the nature and scope of bio-induced COVID- 19 crises are complex, unorthodox and ever-changing; the NA's preparedness requires consistent focus on combating the COVID-19 pandemic. The NA's unique experience with the COVID-19 crisis has demonstrated the need for reappraisal of Nepali Army's strategies and doctrines to effectively contribute in safeguarding the nation's health as an inextricable part of the nation's security.

\section{Analysis of Causes of Spread}

Nepal has adopted diverse management strategies to prevent COVID-19 outbreak. At this point, it is pertinent to look inward as to why Nepal did well with the earliest cases and failed to contain subsequently. Possibly the following section casts light on the rapid spread of virus.

\section{Incoherent Strategy}

Nepal's strategy for combating COVID-19 appeared reactive and incoherent. It caused the virus to spread swiftly and undetected across the nation. For example, it resulted delays in purchasing essential medical equipment for 
virus tests from China and sent confusing messages about public health practices. Further, Nepal lagged behind its neighbors in implementing non- pharmaceutical interventions, social distancing and other restrictions. Nepal government imposed nationwide lockdown on 24 March 2020 only after the announcement of the second positive case of COVID-19.

\section{Corruption}

Rampant corruption has long been a problem in Nepal. For instance, the medical equipment procurement scandal is a case in point. The government on March 25 had awarded Omni Business Corporate International the tender to purchase medical equipment from China. The Parliamentary Accountability Committee, in its preliminary report, said that Omni Business Corporate International had procured N95 masks at Rs 828.67 per piece, even though the market rate was just Rs 462.50. Non-contact thermometers were purchased for Rs 7,500 each, but the market rate was only Rs 4,000 in February. (The Kathmandu Post, June 23, 2020)

\section{Weak State Capacity}

Nepal's weak state capacity resulting poor emergency service response aggravated the situation. According to the Economist Intelligence Unit in cooperation with the Nuclear Threat Initiative and the Johns Hopkins Centre for Health Security, Nepal ranks 111th among 195 countries in the Global Health Security Index in terms of health security - pandemic preparedness and capacity (Himalaya Times, 2020). Maharjan ET. al ( 2020, p. 10 ) rightly emphasize that at this stage, the major challenges while performing emergency service has been managing triage, human resources, limited stock of personal protective equipment (PPE), proper management of infection prevention and limited laboratories for testing. Such triage management has been sorely lacking in the context of Nepal.

\section{Infodemic}

Another important cause of rapid spread of virus is infodemic-misinformation about the COVID-19. According to American Journal of Tropical Medicine and Hygiene (2020), a study has revealed that so-called "infodemic", about COVID-19 treatment, exacerbated corona misery through the spread of rumors and conspiracy theories. It has led to the deaths to at least some 800 people and possibly more. Likewise, anti-social bravado (I am not afraid of a disease) mentality further aggravated the situation.

\section{Medical, Advancement and Innovation}

Research, innovation and advancement in medical research are the three critical pillars of pandemics response. As of February 5, 2021, Sputnik V, Pfizer, Oxford-Astra Zanecia and Shinovac vaccines are in use to treat corona virus. Some 100 vaccine candidates are currently in the development pipeline for COVID-19. Though, none of them is from Nepal, it's inspirational for us also to embark research in pandemic. One major challenge in pandemic preparation is shock and forgetting. Frequently leaders make resource promises during the crisis for Medical, Advancement and Innovation but those pledges lapse as the memory of the outbreak fades.

\section{Failure of Global Institutions}

The inefficiency of regional and global organizations in the response to the pandemic is deteriorating the crisis. For example, the United Nations, the World Health Organization, SAARC and BIMSTEC could not prove its efficiency during pandemic when people needed the world to act together the most. Walsh (2020) aptly notes the World 
Health Organization, which performed so well under the stress of SARS, has botched more recent outbreaks so badly that experts have called for the entire organization to be overhauled.

\section{Information Delayed}

Belated sharing of information about COVID-19 led to spread of virus across the globe. China publicly shared the genetic sequence of COVID-19 on 12 Jan 2020. (WHO, 27 April 2020), thus the COVID19 case was informed to the outside world belatedly. Kapur and Suri (2020) aptly expose that China's actions and inactions led to an explosion in global infections. It repeated claims against human-to-human transmission, delayed sharing critical information, suppressed research about the virus, and allowed travel within the country despite knowing the threat.

\section{Narrow Self-Interest of Nations}

The primary defective thinking in the COVID-19 response has been due to narrow self- interest of nations. Many powerful nations are also failing in containing this pandemic. Developing countries like Nepal have no option but to respondin self-help in order to curb the spread.

\section{Consequences and Impact}

The impact of pandemic has been universal and multi-dimensional in nature. Some of the key consequences and impacts of COVID- 19 in Nepal are discussed in succeeding sections.

Political disruption: Pandemic can create political disruptions severely affecting state affairs. Protection of people, political order and preservation of economic integrity form an important part of the overall security of a nation. Pandemics can peril those elements including political stability. For example, the current unstable political situation in Nepal is somehow connected with the handling of COVID-19 crisis including rampant corruption.

\section{Health Security}

The pandemic is a national security issue which has been taking a heavy human toll in Nepal. As Beauregard \& Kazemi (2020) rightly emphasize that public health security is national security and nothing is more fundamental to a state's security than the health of its people. If people are unhealthy, they cannot work. If they cannot work, they cannot contribute to the economy. If they cannot contribute to the economy, the government cannot provide services and infrastructure. If the government cannot provide services and infrastructure, then they are persistently vulnerable to security threats from state and non-state actors or from natural threats like climate change and diseases.

\section{Food Security}

The Covid-19 pandemic is threatening the food security of Nepal. Adhikari (2020, p. 120) aptly notes the daily supply becomes limited, production remains low, unemployment rises, transport shut down, scarcity in the market place becomes rampant and prices rise. Thus, it has negatively impacted all four aspects of food security, namely, availability, access, stability, and utilization of food.

\section{Extremism/Terrorism}

COVID-19 brings in new security challenges for Nepal. Nepal already has internal security issues related to armed elements and insurgent movement. Thus it faces difficult task of dealing with two threats (the COVID-19 and the insurgents) concurrently.

\section{Cyber Terrorism}

As the Coronavirus spreads across the country, 
cyber criminals are taking advantage of crisis situation. They are attacking the computer networks and systems of individuals, national and international organizations. So Nepal is faced with an unprecedented cyber threat to national security during pandemic era.

\section{Great Power Rivalry}

Pandemic can also impact relationship between states. For example, the Sino US bilateral relations deteriorated following the blame game on origin of corona virus. President Donald Trump says the coronavirus pandemic is a worse "attack" than Pearl Harbor and 9/11(BBC, 2020) where as China counter claims that the corona virus entered Wuhan, China with U.S. military personnel during the World Military Games in 2019.

\section{Terrible Economic Consequences}

The Corona pandemic has hit hard the economy of Nepal spanning at both macro and micro levels. It is illustrated by the impact assessment of the World Bank. Nepal's economy is projected to grow by only 0.6 percent in 2021, inching up from an estimated 0.2 percent in 2020 as lockdowns caused by COVID-19 disrupt economic activity, especially tourism, says the World Bank's latest South Asia Economic Focus, Beaten or Broken (WB, 2020). Further, there is significant fall in remittance inflow. Above all, it will be difficult to achieve Sustainable Development Goal (SDGs) for ending poverty 2030 .

\section{Indo-Nepal Border Crisis}

Unprecedented serious territorial threat to national security can crop up during pandemic crisis. For example, the territorial dispute between India and Nepal came to light in COVID-19 situation when India unilaterally inaugurated strategically important road on 8 May 2020. This road was about $80 \mathrm{Kms}$ along the India Nepal border to the disputed area up till Lipulekh (Dalal, 2020, p. 1). As this action of India shocked the people in Nepal, then the Nepal government justifiably released a new map of Nepal on 20 may 2020.

\section{Nepali Army}

The COVID-19 pandemic has forced the Security sector including Nepali Army to operate in alternative ways. Albeit, NA is unlikely to recall troops from overseas Peace Keeping deployments to augment the paucity of human resource at home, the COVID-19 crisis has impact on its routine military movements, training, operational readiness and other administrative functions.

\section{Recommendations}

In view of above mentioned causes and consequences, nature and scope it becomes apparent that there can be no technicallyoriented quick panacea in such pandemic crisis situation in Nepal. There are four critical areas in which a strategic response must be focused: pandemic detection, containment, rule of law monitoring, and prevention of future diseases. To that end, the following strategic options are proffered to ensure that infectious disease like COVID-19 outbreaks are detected, prevented, and contained in the country.

\section{Integrated National Security Strategy (INS)}

The nature, scope, novelty and complexity of COVID - 19 pandemic demands an integrated national security strategy with an effective application of all the instruments of national power, including Nepali Army, public and private sector to effectively respond it. The strategy should place the protection of people at the core of efforts to efficiently contribute in alleviating the worst consequences the pandemic could have. 


\section{Health Strategy}

Health care should be considered basic human rights in letter and in spirit. And, Nepal should have an effective health strategy reflecting this priority. The health strategy must entail capacity building of health care systems including promotion of health coverage, medical research, mapping of resources, vaccine development. To that end Nepal should spend more on the heath care system of the country. At this point, it will be unjust not to acknowledge the service of health professionals and incorporate their valuable advice in the strategy. Should there be national will, it's very much possible to have effective health strategy. For example, the Sri-Lankan government's response to the current COVID-19 crisis has been largely successful and is ranked among the best responsive countries in the world (Senevirathna, 2020, p. 147).

\section{Economic Strategy}

Nepal should formulate and implement Comprehensive Economic Development Strategy (CEDS) to resuscitate the ailing economy due to pandemic. According to the WB (2020), in Nepal, growth is expected to fall to a range between 1.5 and 2.8 percent in FY20 reflecting lower remittances, trade and tourism, and broader disruptions caused by the COVID-19 outbreak. A prolonged outbreak of COVID-19 would impact growth significantly with a further deceleration or contraction in services and industrial production. Economic growth during FY21 is also likely to remain subdued due to the lingering effects of the pandemic with some recovery expected in FY22.

\section{Environmental Security}

Indeed, the COVID-19 pandemic is a wakeup call to better manage our relationship with nature. It is a symptom of destruction our environment and natural world. Therefore, strategy should also promote environmental protection taking into cognizance the fact that restoring climate stability is our ultimate security.

\section{Unified Approach}

Whole of society should exhibit will power to curb the spread of disease. Communities should be prepared to educate, provide for, and undertake strict measures to contain the spread of infectious disease. For example, a community led public health movement immensely contributed to terminate the great European cholera epidemic.

\section{Information}

To contain the pandemic, the importance of collecting accurate, scientificpublic health data, analyzing the virus origins, characteristics, and spread of the virus, information dissemination and sensitization to the people cannot be overemphasized. Nepal must have an effective information system in place.

\section{Observe Protocols}

It is very important to strictly observe government policies such as social-distancing and self-isolation etc. Everyone should sincerely cooperate and observe government issued protocols to halt the spread. For example, research suggests that China's nonpharmaceutical interventions, such as travel bans, social distancing, isolation, and contact tracing, were effective to halt the spread of the virus.

\section{Research}

National efforts must be directed towards research, innovation and advancement in medical research in Nepal as Lamichhane \& Ghimire( 2020, p. 9) point out that the most 
effective measures to control the spreading of $\mathrm{nCoV}$ are to obtain its vaccination and to break the chain of its transmission. The annual budget for fiscal year 2020/21, with an increase by $31.8 \%$ in health sector is inadequate to focus on rebuilding public health capacity including research and medical advancement.

\section{Anti-corruption}

Strict anti-corruption measures must be adopted and enforced now to prevent the fallout of bad actors later as late King PN Shah said "Ghush khnayalai thoknyahun (Corrupt must not be spared, Divyopdesh, 2059, p. 46)" One corrupt actor in the response chain can destroy the image of the institution. The Ebola response showed that corrupt individuals taking bribes can compromise security and the health of many (Wermuth, 2020). In the early days of COVID-19 crisis situation, Nepali Army was entrusted to purchase medical equipment due to lack of confidence in OMNI group.

\section{Learn lessons}

Key lessons are useful to make adjustments to our pandemic crisis response strategies. These lessons can guide decisions to help reduce economic and social impacts. For example, learning lessons from the 2002-2004 SARS outbreaks, the countries of Asia Pacific region proactively adopted non-pharmaceutical initiatives including travel controls, border closures and lockdowns along with enhanced health and medical coverage.

\section{Cooperation}

It is almost impossible to contain the pandemic like COVID-19 alone. Deep inter -regional cooperation is required to overcoming it. Mierins (2002, p. 183) aptly notes "[m]icrobial threats to human health do not respect international borders and are extremely difficult tomonitor and contain. Infectious disease constitutes a truly global challenge, and such it must be met with international cooperation".

\section{National Unity}

Like any crisis COVID-19 pandemic has positive aspects also. For example, it provides an opportunity to reinvigorate national solidarity, unity and cooperation. If we stand united for coordinated response, we will certainly win this war.

\section{International Organization}

The World Health Organization (WHO) and the United Nations must play effective roles to coordinate the efforts of nation-states and to limit the effects of the disease through the formation of a technical solution.

\section{Cyber Security}

During pandemic situation, Cyber security is everyone's concern. Policymakers need to take the cybercrime threat seriously and come up with a comprehensive cyber security policy to improve the security of their citizens and businesses in Nepal.

\section{Nepali Army}

The heavy involvement of security sector including Nepali Army in the fight against COVID-19 has had a positive impact on the outcome. For example, Prime Minister KP Sharma Oli has lauded the role played by the Nepal Army in the fight against novel coronavirus (My Republica, 2020). However, adequate resources need to be provided to further enhance their efficiency. Further, Nepali Army with its experiences in the campaign against corona virus needs to revise it strategies and doctrines to enhance its efficiency and effectiveness in the coming days. 


\section{Conclusion}

The ongoing COVID-19 pandemic, a nonmilitary asymmetric threat has far-reaching multi- dimensional security implications. To effectively deal with it, requires proactive and coherent strategic response which should place the protection of people at the very core of efforts. In other words, to put it candidly the preparation for the widespread pandemics disease like COVID-19 should be a key focus of national security because the nature, scope, novelty and complexity of COVID -19 pandemic demands an integrated national security strategy with an effective application of all the instruments of national power, including Nepali Army, public and private sector to respond effectively. To do that, we need change in mindset of leadership in reframing the new security paradigm. Holding on to age old lens of merely state centric security policy overlooking citizens' health cannot help us to deal with emerging challenges posed by non- military threat like COVID 19. For this, we have to securitize burning health concern corona. If need be, pandemics such as COVID- 19 should be classed as a Tier 1 national security risk and that should be reflected in the resources. Meanwhile, Nepali Army learning from the campaign against corona virus, should concurrently leave no stone unturned to prepare strategies and doctrines based on above mentioned new integrated national security strategy.

\section{References}

Adhikari, A.S. (2020). Viewing Microorganisms through the Lenses of Realism. Tribhuvan University Journal COVID-19 Special Issue Vol.34 115-122 September. Centre of Research Tribhuvan University, Kathmandu, Nepal
Beauregard, J \&Kazemi, R. (2020) Health Security is National Security, New Security Beat April 28, 2020 https://www. newsecuritybeat.org/2020/04/health-securitynational- security/

Chaudhary, A. (2020). COVID-19, Remittance Inflow and Economic Growth Rate in Nepal. Tribhuvan University Journal COVID-19 Special Issue Vol.34. pp 69-80 September. Centre of Research Tribhuvan University, Kathmandu, Nepal

Cohen, Z., Marquardt, A. \& Atwood, K. (2020). Blame game escalates between US and China over coronavirus disinformation $C N N$ March 25,2020

COVID-19 Mahamari: Niyantran, Upachar Ra Pratikaryama Nepali Sena Sakriya, Sipahi Quarterly, 1 Asar 2077 BS.

Dalal, S. (2020), Relations between India and Nepal in COVID-19 Situation, Journal of Historical Archaeology \& Anthropological Sciences Vol 5 Issue 5-2020, pp 1-3. https://medcraveonline.com/JHAAS/ JHAAS-05-00232.pdf

Evans, J. (2010) "Pandemics and National Security", Global Security Studies, Vol. 1, Issue 1, 2010, p. 3.

George, V. \& Payne, I. (2020). A crisis with opportunity for Nepal Charting a course to better days, Asia \& The Pacific Policy Society, 19 May 2020 https://www.policyforum.net/acrisis-with-opportunity-for-nepal/

Kujur, R. K. (2020) Critical Connection: COVID-19 Pandemic and National Security, Society for the Study of Peace and Conflict, Fostering Ideas Research and Dialogue, May 11, 2020

Lamichhane, T.R., Ghimire M. P. (2020). Research on Covid-19 from Biophysical Perspective, Tribhuvan University Journal, COVID-19 Special Isssue, Vol 34, September 2020, pp. $1-14$ 
Maharjan, R.K., Shrestha, J., Shakya, Y.M., Acharya, R.P., Prasad, P. N. (2020). Tribhuvan University Journal, COVID-19 Special Issue, Vol 34, September 2020, pp. 59-68

Mierins, A. M. (2002). The Health of Nations: Infectious Disease, Environmental Change, and Their Effects on National Security and Development. MIT Pres 2002; p. 183.

Ministry of Defense (2016). National Security Policy 2016. Singhdurbar, Kathmandu

Ministry of Information \& Communication (2059 BS), Kathmandu, Dibyopadesh, p. 46.

National Defense University and CACI International Inc (NDU \& CACI, 2008). Dealing with Todays Asymmetric Threat to U.S. AND Global Security, pp. 2-35. The Asymmetric Threat Symposium Series two. October, 20008

National Intelligence Council United States (2000). The global infectious disease threat and its implications for the US http://www. fas.org/irp/threat/nie99-17d.htm.

National Security Strategy and Strategic Defense and Security Review, A Secure and Prosperous UK 2015, Presented to the Parliament by Command of Her Majesty, November 2015. p. 15

Operation Covid-19 Nepal Ra Nepali Sena. Sipahi Quarterly, Chaitra 1, 2077. Directorate of Public Relations, p. 1-3

Peterson, S. (2002). "Epidemic Disease and National Security." Security Studies, Vol.12, Issue 2, 2002, pp. 43-81.

Preble, C. A. (2020), How Will COVID-19 Change US National Security Strategy?

PM Oli Lauds Nepal Army role in fight against COVID 19. My Republica April 8, 2020 https://myrepublica.nagariknetwork.com/tag/ cadet_basic_course
Responsible Statecraft on April 8, 2020 https:// www.cato.org/publications/ commentary/ how-will-covid-19-change-us-nationalsecurity-strategy

Saving Life of People Is First Priority: PM, The Rising Nepal, Interview 15 November 2020 https://risingnepaldaily.com/interview/savinglife-of-people-is-first-priority-pm

Senevirathna, A. (2020). Sri-Lanka and the COVID-19 Crisis: Strategies and Future Challenges. Tribhuvan University Journal COVID-19 Special Issue Vol.34 147-158 September. Centre of Research Tribhuvan University, Kathmandu, Nepal

Silk, J. (2020) Spread of coronavirus fake news causes hundreds of deaths American Journal of Tropical Medicine and Hygiene, August,

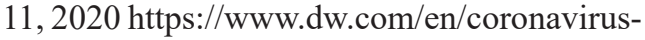
misinformation/a-54529310.

The Kathmandu Post, June 23, 2020

United Nations Nepal (2020), COVID-19 Nepal: Preparedness and Response Plan (NPRP), April 2020.

Walsh, B. (2020) Covid-19: The history of pandemics, BBC 26th March 2020, https:// www.bbc.com/future/article/20200325-covid19-the-history-of- pandemics

World Bank (2020) COVID-19 impact on Nepal's economy hits hardest informal sector, Press Release https:/www.worldbank.org/en/news/ press-release/2020/10/08/covid-19-impacton-nepals-economy-hits-hardest-informalsector

WHO (2020) Nepal Situation Updates on COVID-19https://www.who.int/nepal/ news/detail/05-02-2021-who-nepalsituation-update 